\title{
Daisy Murray. Twins in Early Modern English Drama and Shakespeare. London and New York: Routledge, 2017. Pp 201. Hardback USD \$150.00. ISBN: 9781138679368.
}

\section{JESS HAMLET}

\section{University of Alabama}

Daisy Murray's new book on twins and twinning in early modern English drama begins by situating dramatic representations of twins within the larger early modern culture of thought around the unnaturalness of twins in popular culture and scientific literature. In doing this crucial contextual work, Murray sets out to refresh our thinking on what it meant to be a twin or be related to a twin in early modern England and to lay the foundation for her readers to understand the possibilities for monstrosity and surprise that twins presented in early modern drama. She drives home the variety of interpretations open to early modern people when encountering twins, most often through literature of some kind, but aims to recast twins not as the 'objects of horror' of many early modern representations but as 'objects of wonder' (182). Her use of both medical literature and cheap print such as broadsides and ballads gives evidence of the representation of twins in early modern England as 'prodigious figures' who appeared alongside 'moralizing messages' and gave rise to reams of medical literature blaming women for 'imperfections' in the children they bore $(3,9)$. Murray's thorough survey of medical manuals feeds productively into the discussion of William Davenant's The Cruel Brother (1627) in chapter one and Richard Brome's The Lovesick Court (1638) in chapter two. Here, she focuses her thinking on the alignment of the female character with the space of the womb, drawing on early modern scientific discussion of the womb as 'the site of generative activity' (8). In sum, Murray's formative contextual work on non-dramatic literature surrounding twins and twinship is the base on which she rests her assertion that these cultural markers contributed to and influence both modern and early modern readings of the twin relationships in the plays she discusses.

The bulk of Murray's text is devoted to working through dramatic representations of twins in tragedies (John Webster's The Duchess of Malfi and William Davenant's The Cruel Brother), tragicomedies (Webster's The Devil's Law Case, William Ryder's The Twins, and Richard Brome's The Lovesick Court), comedies (James Shirley's Changes: or, Love in a Maze; Thomas Middleton's A Chaste Maid in Cheapside; Patient Grissil by Thomas Dekker, Henry Chettle, and William Haughton), and two of Shakespeare's comedies (The Comedy of Errors and Twelfth 
Night). By organizing her book in this way, she shows both the ways in which representations of twins are bound by genre and how the non-dramatic literature surrounding twins manifests itself in dramatic representations of twins. In the tragedies, for example, Murray argues that the unnatural nature of twin births (as propounded by the period's medical literature) carries forward into the unnatural behavior of the twin characters. Both sets of male/female twins in the two plays she discusses in this section 'create binaries of their twin characters' and in so doing, set the brothers in opposition to their sisters (58). Each brother destroys his sister, but as they are indissolubly linked to each other, so each brother is the author of his own destruction. As Murray maps twins through the remaining plays in her book, she notes the shift from negative depictions of twins in the tragedies to more (but not wholly) positive depictions in the comedies. The tragicomedies are the unsurprising middle ground of twin representation, removing or changing the twin relationship in such a way as to allow for a comic ending free of the negative effects of twinship apparent in the tragedies.

A particular strength of the book is Murray's juxtaposition of twins in academic comedies, mainstream non-Shakespearean comedies, and Shakespearean comedies. In the three professional plays she discusses in her comedy chapter she notes 'while the negative associations with twinship are overridden, they are not necessarily directly addressed and, accordingly, the horrific possibilities still linger over these plays' (137). When compared with the academic plays she discusses in this chapter, Ignoramus and Senile Odium, the professional plays reframe this lingering negativity as somewhat more nuanced - the academic plays use twin characters as 'an image of doubleness' that obscures identity for comedic purposes, making 'imitatio, not twinship, the main focus of these academic dramas' (137). Taken together, both the comedies and the academic plays 'naturalize the twin relationship' and allow for a more positive representation of twins in the early modern period. In The Comedy of Errors and Twelfth Night, however, Murray argues that Shakespeare develops the twin condition into something unambiguously positive and perhaps even desirable. In Shakespeare's plays, 'twinship is celebrated in its own right' as The Comedy of Errors and Twelfth Night 'build toward a comic conclusion grounded in the reconciliation of twin siblings and the accompanying assertion of the establishment of the twin relationship as a positive solution within the action' (144). Importantly, Murray's interpretation of these plays hinges on Shakespeare's reference to and rejection of the popular, negative understanding of twinship in order to create 'the strongest argument for a positive understanding of twinship' in the early modern period (144). She further takes up the question of Shakespeare's own experience as the father to twins, one of whom was untimely 
lost. While Murray agrees with the obvious biographical parallel to Twelfth Night that other critics have mentioned, she makes a case for the importance of Shakespeare's personal interest in twins and twinship to the composition of The Comedy of Errors as well. She points out that Comedy, taken together with some of Shakespeare's business dealings in the late 1590s, points to a Shakespeare 'invested in promoting a positive depiction of the situation of his children - namely, the twin condition of Judith and Hamnet' (146). (As example of legal transactions that point to a Shakespeare concerned with the welfare and reputation of his family, Murray gestures to Shakespeare's role in his father's acquisition of a coat of arms in 1596 and his purchase of New Place as the family home.) Ultimately, Murray argues, Shakespeare's twin comedies reframe the twin condition as 'a source of pleasure and enjoyment' and are responsible for 'the movement of twinship into the realm of the natural' (175).

If one must take issue with any part of this book, it is that a study titled Twins in Early Modern English Drama and Shakespeare might reasonably be expected to give equal weight to Shakespeare and non-Shakespearean drama rather than relegating Shakespeare to a single chapter. Murray's discussion of Shakespeare is so fruitful that one almost wishes she had devoted an entire chapter to each of his two plays, or that she had delved further into the gender politics at work in them. As it stands, however, the book gives us a thorough study of the plays and answers more questions than it leaves unasked.

As a new work on an often-discussed but rarely properly studied facet of early modern drama, Murray's text is valuable, but where it shines is in its consideration of non-dramatic representation and culture. This book is undeniably within the realm of theatre and theatre history, but it is also a work of social and cultural history around ideas of conception, childbirth, science, and gender. As a resource for scholars thinking about drama, genre, families, twins, science, non-dramatic literary culture, or any one of a number of other specific subtopics, this text is a fresh, insightful volume that will surely open up new avenues of inquiry for its readers. 
